\title{
Green human resource management: how to implement environmental issues into $H R$ practices
}

\author{
Svitlana Tsymbaliuk ${ }^{1,}{ }^{*}$, Alla Vasylyk $^{1}$, and Khrystyna Stoliaruk ${ }^{1}$ \\ ${ }^{1}$ Kyiv National Economic University named after V. Hetman, 54/1 Peremohy Ave., 03057 Kyiv, \\ Ukraine
}

\begin{abstract}
The purpose of study is to analyze the spread of practices of GHRM in Ukraine and develop conceptual basis for the implementation of environmental issues into HR practices. The paper focuses on the providing integrated approach to GHRM practices, which should be implemented in all HRM functions. The article contains important theoretical and methodological principles for research of GHRM. The research showed that the GHRM could be seen as a tool for implementing corporate social responsibility programs related to environmental protection. Furthermore, GHRM covers a wide range of practices related to encouraging environment friendly behaviour and innovative environmental initiatives of employees. The analysis has shown that the green issues and development of the green economy are relevant for Ukraine, but the GHRM practices have not become widespread. This has been confirmed by the results of analysing job advertisements in the HRM sphere, posted on the most popular job sites. The article contains directions for increasing awareness of owners, managers, HR specialists on GHRM practices: implementation of relevant courses in universities' educational programs, certification programs, development of training programs, initiation of round tables and conferences on GHRM issues.
\end{abstract}

\section{Introduction}

Environmental sustainability is one of the significant characteristics interfusing most of Sustainable Development Goals. Strategies of sustainable development are rapidly developing in different companies in response to challenges and cataclysms caused by destruction of ecosystems, environmental pollution and climate change. The increasing role of sustainable development leads to implementation of environmental issues into companies' mission, objectives, and policies in all functional spheres, including human resource management (HRM). HRM, which implements environmental (green) policies into human resource practices, is named green human resource management (GHRM).

The purpose of study is to analyze the spread of practices of GHRM in Ukraine and develop conceptual basis for the implementation of environmental issues into HR practices.

\footnotetext{
${ }^{*}$ Corresponding author: tsymbaliuk_svitlana@ukr.net
} 
The hypothesis of the study $(\mathrm{H})$ : although the issues of environmental protection and development of the green economy are extremely relevant for Ukraine, the practices of GHRM have not become widespread.

\section{Literature review}

Many scientists [1] studied issues related to GHRM. Some studies are devoted to examination of awareness of GHRM among different categories of personnel including HR from various organizations. They shows that despite high level of awareness, GHRM practices are still not wide spread. For this reason, organizations want to implement the GHRM policy in future.

Some scientists studied the impact of GHRM practices on green innovation, green behavior, and environmental sustainability. S.K. Singh, M. Del Giudice, R. Chierici, D. Graziano [2] made conclusion that GHRM practices facilitates the influence of green transformational leadership on green innovation and GHRM indirectly through green innovation influences corporate environmental performance.

Y. Zhang, Y. Luo, X. Zhang, J. Zhao [3] studied how GHRM practices influence the employees' green behavior. The research shows that employees' life cycle, education and training, employees' empowerment, and managers' involvement affect the green behavior of employees positively, while rewards only significantly predict extra-role behavior.

The results of study Y. Jehan, D. Hussain, M. Batool, M. Imran [4] showed that GHRM practices impact directly on environmental sustainability while the indirect relationship between green training and sustainable environment through "pro-environmental behavior".

The authors [5] identified challenges in applying GHRM practices in the enterprises such as a low level of knowledge, no rules for practicing, a lack of administrative interest and support, high expenses of practicing, and high employee turnover.

Some research in the field of GHRM are aimed at highlighting the specifics of the various HRM functions in the context of the implementation of GHRM policies.

P. Mishra [6] studies such GHRM practices as recruitment, performance appraisal, training, compensation, and involvement of employees. The author suggested further development of GHRM potential for encouraging pro-environmental behavior.

The findings of the study [7] highlighted GHRM practices under the different HRM functions: job design and analysis, HR planning, recruitment, induction, performance evaluation, training, reward and discipline management, health and safety management and employee relations.

A. Engin, O.M. Karatepe, H. Rezapouraghdam and T. Avci [8] distinguished eight GHRM practices: selective staffing, green training, green empowerment, green rewards, green teamwork, green career opportunities, green work-life balance, and green participation in decision making.

G. Tang, Y. Chen, Y. Jiang, P. Paillé, and J. Jia [9] considered that GHRM includes five dimensions: green recruitment and selection, green training, green performance management, green reward, and green involvement.

The study of C. Cabral and R.L. Dhar [10] is aimed at developing green competencies. The main conclusion of the study: green competencies is a multi-dimensional scale, which comprises of dimensions such as green knowledge, skills, abilities, attitudes, green behavior and awareness.

Some research in the field of GHRM are devoted to practices of implementation of GHRM into different HRM functions: recruitment and selection [11], green training [12], and green corporate culture [13].

Based on the generalization of the approaches of different scientists, we formulated important theoretical and methodological principles of research of GHRM: 
- GHRM focuses on the environmental sustainability of society, and therefore it is one of the most promising directions of HRM development;

- despite the awareness of the importance of implementing GHRM practices, results of research showed that they are not widespread in practices;

- the support of the company's management is the key to successful implementation of GHRM practices.

Despite the development of theoretical and practical research in the field of GHRM, the issues of implementation of GHRM practices in HRM functions remain relevant. It is lack of research based on integrated approach to developing green HR strategy, which covers all HR functions, not only traditional ones (recruitment and selection, adaptation, training and staff motivation).

Important functions are designing organizational structure with centers of responsibilities for implementing green policies, development of green corporate culture and communication, formation of environmental protection mindset, developing green EVPs, etc. An important area of research is the study of the role of GHRM in the current COVID-19 pandemic situation, in which the role of occupational safety and health management are essentially increasing.

\section{Results}

The specific of GHRM is the focus of HR managers and leaders on developing and implementing environmental policies into HRM practices and encouraging environment friendly behavior, innovative green initiatives of employees and promoting sustainability of organization's resources. GHRM includes green HR strategies, policies, practices, and systems.

Conceptual basis for the implementation of GHRM is shown in the Fig. 1.

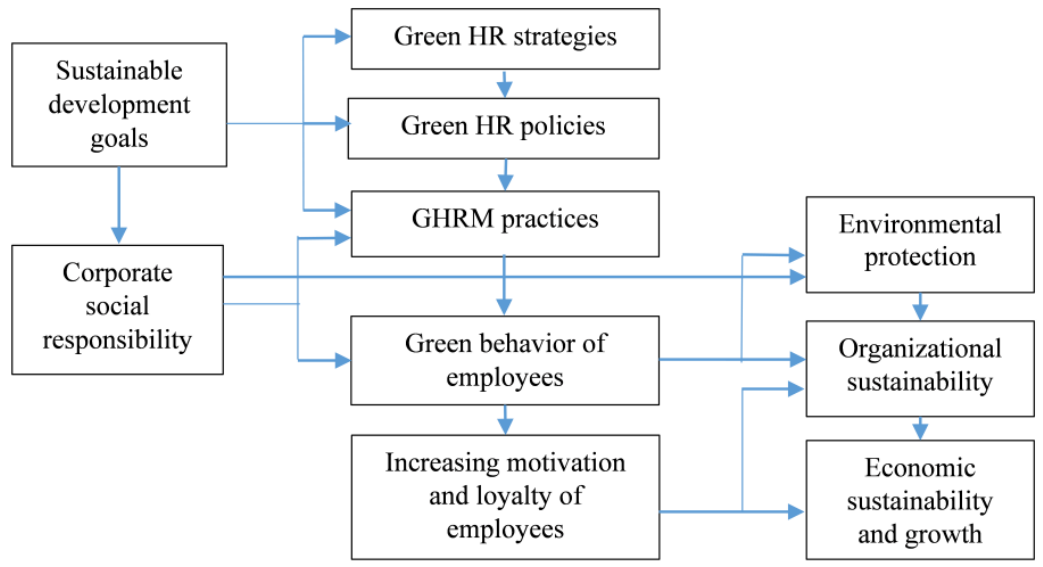

Fig. 1. Conceptual basis for the implementation of GHRM.

It is important to provide an integrated approach: GHRM practices should be implemented in all HRM functions. Environmental policies should be included into HR policies and all its components: recruitment policy, training policy, compensation policy, etc.

GHRM practices in accordance with HRM functions are shown in the Table 1.

There is a close relationship between GHRM and corporate social responsibility concept, as both are related to the implementation of environmental sustainability in the 
business practices and business processes and contribute to sustainable development, including public health and well-being. Therefore, it is important to differentiate these areas of activities.

Social responsibility is a concept that encourages managers, including HR managers, to take into account the interests of society, taking responsibility for the impact of activities on consumers, stakeholders, employees, community and environment in all aspects of organizations' activities. Corporate social responsibility programs include procedures and practices of organizations in various aspects of activities: organizational management, ethical operations, human rights, labor relations, environmental protection, consumer protection, development of local communities and cooperation with them.

GHRM, as we have already noted, is the direction of HRM that is related to development and implementation of environmental policies into HRM practices. Therefore, GHRM has respect to only one aspect of the implementation of corporate social responsibility programs - environmental protection. In this regard, GHRM can be seen as a tool for implementing corporate social responsibility programs related to environmental protection. However, GHRM is not limited to implementation of environmental programs as a component of corporate social responsibility programs. GHRM covers a wide range of practices related to encouraging environment friendly behavior and innovative environmental initiatives of employees (Table 1).

GHRM should be deeply integrated into the company's environmental management system and focus on long-term sustainable development goals. This approach has such multiplier effect as improving the company's environmental image and its environmental competitiveness, reducing environmental risks and losses from their consequences. This approach as well involves employees in environmental activities, supports their green behavior and encourages achievement of environmentally oriented goals and indicators.

GHRM is also one of the factors in improving the company's image, including its employer brand. The modern companies through GHRM can promote themselves as green employers because people prefer to work for companies with sustainable (green, environmentally friendly) corporate culture. Thus, their attractiveness as the employers increases what allows them to recruit and retain the best employees.

In current pandemic COVID-19 situation the role of the health and safety management is increasing. So the creating a socially responsible, resource productive and environmentally sensitive workplaces, developing safe work conditions, improving employees' health, reducing stress and occupational disease caused by unhealthy environment are the main tasks of the employer in this area. Therefore, the HRM tasks should focus on changing the organizational aspects of personnel labor activity, preventing professional burnout, reducing threats to life at work, and maintaining physical, mental and psychological health of employees. GHRM should become a new philosophy and culture of HRM, aimed at the retention and using human potential in the best way, providing the occupational health and well-being of staff. In this context, an important direction is the study of the labor protection management, and such activities as the management of technical safety, occupational health, the management of labor protection culture, labor protection psychology.

The green issues and development of the green economy are relevant for Ukraine. Socially responsible companies develop green management policies and have good experience in implementing some GHRM practices. But unfortunately this is not a widespread practice.

During February-March 2021, the authors analyzed job advertisements in the HRM sphere, posted on the most popular job sites. The basic data are shown in the Table 2. 
Table 1. GHRM practices in accordance with HRM functions.

\begin{tabular}{|c|c|}
\hline HRM functions & GHRM practices \\
\hline $\begin{array}{l}\text { Organizational } \\
\text { design and staff } \\
\text { planning }\end{array}$ & $\begin{array}{l}\text { Designing organizational structure with centers of responsibilities for } \\
\text { implementing environmental policies } \\
\text { Institutionalizing jobs and positions responsible for environmental issues, for } \\
\text { example, green finance, green HRM } \\
\text { Forecasting a number of employees necessary for implementing environmental } \\
\text { initiatives and green activities }\end{array}$ \\
\hline $\begin{array}{l}\text { Job analysis and } \\
\text { job design }\end{array}$ & $\begin{array}{l}\text { Developing tasks, duties, responsibilities and competencies related to green } \\
\text { (environmental) issues and including them into job descriptions }\end{array}$ \\
\hline $\begin{array}{l}\text { Recruitment and } \\
\text { selection }\end{array}$ & $\begin{array}{l}\text { Developing green (environmental) requirements to applicants } \\
\text { Including environmental values of company into job advertisements } \\
\text { Attracting and selecting applicants with green knowledge and attitudes } \\
\text { Seeking applicants and communicating with them via electronic resources, } \\
\text { minimizing paper usage in selection procedures }\end{array}$ \\
\hline $\begin{array}{l}\text { Onboarding and } \\
\text { adaptation }\end{array}$ & $\begin{array}{l}\text { Highlighting the company's culture of green consciousness, its concerns with } \\
\text { environmental issues and green actions } \\
\text { Integration of new employees with the company's green culture }\end{array}$ \\
\hline HR accounting & Electronic document management \\
\hline $\begin{array}{l}\text { Performance } \\
\text { management } \\
\text { and appraisals }\end{array}$ & $\begin{array}{l}\text { Setting up sustainability goals and developing environmental KPIs for measuring } \\
\text { their achievements } \\
\text { Involving employees into developing sustainability goals and KPIs and } \\
\text { discussion of ways how to improve their performance }\end{array}$ \\
\hline $\begin{array}{l}\text { Training and } \\
\text { career } \\
\text { development }\end{array}$ & $\begin{array}{l}\text { Developing employees' green skills, knowledge, and attitudes } \\
\text { Conducting green training based on employees needs } \\
\text { Teaching employees to reduce waste, save resources, including energy } \\
\text { Encouraging for acquisition of green skills } \\
\text { Promoting employees with environmental management competences }\end{array}$ \\
\hline $\begin{array}{l}\text { Corporate } \\
\text { culture }\end{array}$ & $\begin{array}{l}\text { Developing a sustainable (green, environmentally friendly) corporate culture } \\
\text { Using teamwork for governing environmental issues }\end{array}$ \\
\hline Communication & $\begin{array}{l}\text { Increasing green awareness and formation of environmental protection mindset } \\
\text { via newsletters, briefings, round tables, conferences, publications in website, } \\
\text { social media, etc. } \\
\text { Providing feedback to employees on regular basis concerning implementation } \\
\text { environmental policies }\end{array}$ \\
\hline $\begin{array}{l}\text { Employer } \\
\text { branding }\end{array}$ & $\begin{array}{l}\text { Developing green EVPs which are attractive for people with green behavior } \\
\text { Promotion themselves as green employers }\end{array}$ \\
\hline $\begin{array}{l}\text { Compensation } \\
\text { and benefits }\end{array}$ & $\begin{array}{l}\text { Encouraging employees for being involved in green activities of company by } \\
\text { tangible rewards: salary increase, bonuses, social benefits } \\
\text { Public praising and appreciation for green efforts, environmentally friendly } \\
\text { activities by management } \\
\text { Rewarding for acquiring certificates from awarding institutes }\end{array}$ \\
\hline $\begin{array}{l}\text { Employee } \\
\text { relations }\end{array}$ & $\begin{array}{l}\text { Involving employees into developing green policies and solving environmental } \\
\text { problems } \\
\text { Encouraging innovative company's social and environmental initiatives in } \\
\text { cutting on carbon emissions, reducing waste, etc. }\end{array}$ \\
\hline $\begin{array}{l}\text { Health and } \\
\text { safety } \\
\text { management }\end{array}$ & $\begin{array}{l}\text { Creating a socially responsible, resource productive and environmentally } \\
\text { sensitive workplaces, and safe work conditions } \\
\text { Improving employees' health, reducing stress and occupational disease caused } \\
\text { by unhealthy environment }\end{array}$ \\
\hline $\begin{array}{l}\text { Discipline } \\
\text { management }\end{array}$ & Implementing discipline management for violence of green rules \\
\hline $\begin{array}{l}\text { Leaving the } \\
\text { company }\end{array}$ & $\begin{array}{l}\text { Making exit interviews for assessing the employees' opinion on the company's } \\
\text { green practices }\end{array}$ \\
\hline
\end{tabular}


Table 2. Basic data on the analysis of job advertisements in the HRM sphere.

\begin{tabular}{|l|l|}
\hline \multicolumn{1}{|c|}{ Criteria } & \multicolumn{1}{c|}{ Data } \\
\hline Vacancies & HR Director of Personnel Management \\
& HR Manager \\
& HR Specialist \\
\hline Quantity & 400 \\
\hline Resources & https://grc.ua \\
& https://www.work.ua \\
& https://rabota.ua \\
\hline Period & February - March 2021 \\
\hline
\end{tabular}

The results of the analysis showed that none of the job advertisements contained responsibilities related to GHRM, the implementation of sustainable development and environmental issues in HRM practices. This confirmed the authors' hypothesis $(\mathrm{H})$ about inadequate attention of Ukrainian employers and managers to practices of GHRM.

The results of the study also showed that although no job advertisement contained GHRM responsibilities, companies use some GHRM tools, including the environmental values of the company into job advertisements. For example, job advertisement of Ukrainian pharmaceutical company "Farmak" for the HR manager position included the environmental values as EVPs:

- environmental care, CSR (donation, clean city), Eco-school, Green Office;

- $\quad$ opportunity to join various social events and volunteer activities.

For increasing awareness of owners, managers, HR specialists on GHRM practices, it is necessary to implement relevant courses in universities' educational programs and curricula, certification programs in HRM, develop training programs for HR specialists, organize round tables, workshops, conferences on GHRM issues.

\section{Conclusions}

GHRM is one of the most promising directions of HRM development awareness of HR specialists on GHRM practices. Although the green issues and development of the green economy are relevant for Ukraine, the GHRM practices have not become widespread. This has been confirmed by the results of analyzing job advertisements in the HRM sphere, posted on the most popular job sites. For providing integrated approach GHRM practices should be implemented in all HRM functions: organizational design and staff planning, job analysis and design, recruitment, onboarding and adaptation, HR accounting, performance management and appraisals, training and career development, corporate culture, employer branding, compensation and benefits, employee relations, etc.

GHRM should become a new philosophy of HRM that aimed at developing a sustainable (green, environmentally friendly) corporate culture and using teamwork for governing environmental issues.

GHRM practices should be implemented in all HRM functions. It must include such activities as designing organizational structure with centers of responsibilities for implementing environmental policies; institutionalizing jobs and positions responsible for environmental issues, for example, green finance, green HRM; setting up sustainable goals and developing environmental KPIs; developing employees' green skills, knowledge, and attitudes; increasing green awareness and formation of environmental protection mindset, etc.

Current pandemic COVID-19 situation has maintained the role of the health and safety management as a direction of GHRM and corporate social responsibility. 
Further research should be aimed at elaborating an effective GHRM model, focused both on environmental and social results of corporate environmental responsibility; identification of mechanisms for transformation of HRM into the GHRM; developing tools for integration of GHRM into the environmental management system in a changing environment; working out methods for evaluation of GHRM practices; creating an empirical basis for assessing social, economic and environmental results of implementation of GHRM practices, etc.

\section{References}

1. Mamun, M. (2019). An Analysis of Employee Awareness on Green Human Resource Management Practices: Evidence from Bangladesh. Human Resource Management Research, 9 (1), 14-21. https://doi.org/10.5923/j.hrmr.20190901.03

2. Singh, S.K., Del Giudice, M., Chierici, R., \& Graziano, D. (2020). Green innovation and environmental performance: The role of green transformational leadership and green human resource management. Technological Forecasting and Social Change, (150). https://doi.org/10.1016/j.techfore.2019.119762

3. Zhang, Y., Luo, Y., Zhang, X., \& Zhao, J. (2019). How Green Human Resource Management Can Promote Green Employee Behavior in China: A Technology Acceptance Model Perspective. Sustainability, https://doi.org/:10.3390/su11195408

4. Jehan, Y., Hussain, D., Batool, M., \& Imran, M. (2020). Effect of green human resource management practices on environmental sustainability. International Journal of Human Capital in Urban Management, 5 (2), 153-164. http://dx.doi.org/10.22034/IJHCUM.2020.02.06.

5. Islam, M. A., Hunt, A., Jantan, A. H., Hashim, H., \& Chong, C. W. (2020). Exploring challenges and solutions in applying green human resource management practices for the sustainable workplace in the ready-made garment industry in Bangladesh. Business Strategy and Development, (3), 332-343. https://doi.org/10.1002/bsd2.99

6. Mishra, P. (2017). Green human resource management: A framework for sustainable organizational development in an emerging economy. International Journal of Organizational Analysis, 25 (5), 762-788. https://doi.org/10.1108/IJOA-11-2016-1079

7. Arulrajah. A.A., Opatha, H.H.D.N.P., \& Nawaratne, N.N.J. (2016). Green human resource management practices: a review, Sri Lankan Journal of Human Resource Management, 5 (1), 1-16. http://doi.org/10.4038/sljhrm.v5i1.5624

8. Engin, A., Karatepe, O.M., Rezapouraghdam, H., \& Avci, T. (2020). A Conceptual Model for Green Human Resource Management: Indicators, Differential Pathways, and Multiple Pro-Environmental Outcomes. Sustainability, 12 (17). https://doi.org/10.3390/su1217708

9. Tang, G., Chen, Y., Jiang, Y., Paillé, P., \& Jia, J. (2018). Green human resource management practices: scale development and validity. Asia Pacific Journal of Human Resources, 56 (1), 31-55. https://doi.org/10.1111/1744-7941.12147

10. Cabral, C., \& Dhar, R.L. (2019). Green competencies: Construct development and measurement validation, Journal of Cleaner Production, (235), 887-900. https://doi.org/10.1016/j.jclepro.2019.07.014

11. Pham, D.D.T., \& Paillé, P. (2019). Green recruitment and selection: an insight into green patterns. International Journal of Manpower, 41 (3), 258-272. https://doi.org/10.1108/IJM-05-2018-0155 
12. Pinzone, M., Guerci, M., Lettieri, E., \& Huisinghet, D. (2019). Effects of 'green' training on pro-environmental behaviors and job satisfaction: Evidence from the Italian healthcare sector. Journal of Cleaner Production, (226), 221-232. https://doi.org/10.1016/j.jclepro.2019.04.048

13. Roscoe, S., Subramanian, N., Jabbour, C.J.C., \& Chong, T. (2019) Green human resource management and the enablers of green organisational culture: Enhancing a firm's environmental performance for sustainable development. Business Strategy and Environment, 28 (5), 737-749. https://doi.org/10.1002/bse.2277 